\title{
PTPN22 wt Allele
}

National Cancer Institute

\section{Source}

National Cancer Institute. PTPN22 wt Allele. NCI Thesaurus. Code C49524.

Human PTPN22 wild-type allele is located within 1p13.3-p13.1 and is approximately 123 $\mathrm{kb}$ in length. This allele, which encodes tyrosine-protein phosphatase non-receptor type 22 protein, plays a role in the dephosphorylation of protein-tyrosine phosphates.

Functional PTPN22 gene polymorphisms are associated with susceptibility to insulindependent diabetes mellitus, rheumatoid arthritis, systemic lupus erythematosus, and Hashimoto thyroiditis. 